\title{
Occurrence and removals of micropollutants in water environment
}

\author{
Moon-Kyung Kim ${ }^{1,2}$, Kyung-Duk Zoh ${ }^{1,2^{+}}$ \\ ${ }^{1}$ Department of Environmental Health Sciences, School of Public Health, Seoul National University, Seoul 08826, Republic of Korea \\ ${ }^{2}$ Institute of Health and Environment, Seoul National University, Seoul 08826, Republic of Korea
}

\begin{abstract}
Micropollutants are often discharged to surface waters through untreated wastewater from sewage treatment plants and wastewater treatment plants. The presence of micropollutants in surface waters is a serious concern because surface water is usually provided to water treatment plants (WTP) to produce drinking water. Many micropollutants can withstand conventional WTP systems and stay in tap water. In particular, pharmaceuticals and endocrine disruptors are examples of micropollutants that are detected at the drinking water, ppb, or even ppb level. A variety of techniques and processes, especially advanced oxidation processes, have been applied to remove micropollutants from water to control drinking water contamination. This paper reviews recent researches on the occurrence and removal of micropollutants in the aquatic environments and during water treatment processes.
\end{abstract}

Keywords: Adsorption, Advanced oxidation processes (AOPs), Coagulation, Endocrine-disrupting chemicals (EDCs), Pharmaceuticals

\section{Introduction}

Micropollutants are compounds that are detected in the environment at trace concentrations ranging from $\mu \mathrm{g} / \mathrm{L}$ to below $\mathrm{ng} / \mathrm{L}[1]$. Micropollutants can be composed of various materials and can contain various compounds such as pesticides, pharmaceuticals, cosmetics, flame retardants, perfumes, waterproofing agents, plasticizers and insulating foams [2]. Pharmaceuticals and personal hygiene products (PPCPs) and endocrine disrupting chemicals (EDCs) are among the most frequently detected anthropogenic contaminants in water.

Micropollutants are ubiquitous, and are often used to improve human life. This makes it difficult to control the source of these compounds in the water environment. Many researches on monitoring contamination by pharmaceuticals and EDCs in a variety of environments, such as surface water, groundwater, drinking water and wastewater, have reported significant levels of micropollutants in the water environment [3-9].

Because conventional processes used in wastewater treatment plants (WWTPs) are not designed to remove micropollutants, these can persist in the treated wastewater effluent. As a result, many of these micropollutants can be present in aquatic environments, including surface waters, and surface waters are a threat to the ecosystem and human health. The occurrence of micropollutants in the aquatic environment is associated with a variety of negative effects including short- and long-term toxicity, EDC and antibiotic resistance in microorganisms [10-12].

To date, regulations have been adopted for small amounts of micro-contaminants in some countries and regions, but WWTPs are not subject to consistent emission guidelines and standards for micropollutants. For example, environmental quality standards for a small number of micropollutants (e.g., nonylphenol, bisphenol-A and diiron) have been regulated by the European Parliament through Directive 2008/105/EC [13]. Nonylphenol and nonylphenol ethoxylates are recognized by the Canadian government as a toxic substance [14]. Other micropollutants, such as pharmaceutical and personal care products (PPCPs) and steroid hormones, are not yet on the list of regulated substances. Further studies on the effects of these micropollutants on human health and ecological health are needed to establish regulatory standards for micropollutants.

Although several review papers have been published regarding the occurrence of micropollutants in different water bodies [15-17], still not enough work has been done to provide a comprehensive summary of the occurrence of micropollutants in aquatic systems or the removal of micropollutants in conventional and advanced water treatment processes. In this review, we summarize recent work on the occurrence and removal of various micropollutants via conventional, as well as advanced, water

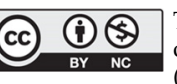

This is an Open Access article distributed under the terms of the Creative Commons Attribution Non-Commercial License (http://creativecommons. org/ licenses/by-nc/3.0/) which permits unrestricted non-commercial use, distribution, and reproduction in any medium, provided the original work is properly cited.
Received September 21, 2016 Accepted November 28, 2016

${ }^{\dagger}$ Corresponding author

Email: zohkd@snu.ac.kr

Tel: +82-2-880-2737 Fax: +82-2-762-2888

Copyright (C) 2016 Korean Society of Environmental Engineers 
treatment processes.

\section{Sources and Transport of Micropollutants in} the Environment

Micropollutants present in the water environment have diverse origins in which domestic wastewater is a major source of surface water (Fig. 1). Pharmaceuticals are frequently detected in aquatic environments, originating from hospitals, drug stores, and convenience stores; some of these drugs are available without prescription (e.g., acetaminophen, ibuprofen, naproxen and aspirin). Although these pharmaceuticals are produced for human and animal healthcare, they are not metabolized completely in the body [18]. Both residual pharmaceuticals and their metabolites are excreted by humans and animals into wastewater. Waste from the manufacture process and from expired drugs can also be sources of pharmaceuticals.

EDCs such as natural hormones, insecticides, nonylphenol, bisphenol-A, and perfluorooctanesulfonic acids (PFOS) are also important micropollutants. These compounds are released into water from raw materials such as plastic products and flame retardants. They can also be generated directly by humans and animals [19, 20]. These hormone-like activities of EDC compounds have been shown to adversely affect human health [21, 22]. EDCs in human body are excreted in sewage and discharged into aquatic systems such as rivers and lakes. For this reason, sewage effluent is considered a major source of micropollutant contamination.

Physicochemical properties and bioavailability can affect the presence of micropollutants in natural waters. Caliman and Gavrilescu [23] categorized the generation and elimination of micropollutants based on five factors; physicochemical properties, environmental factors, transport and retention, transformation and accumulation. The volatility, water solubility, stability of the chemical structure, and particulate distribution characteristics are additional factors that determine whether micropollutants remain dissolved in water.

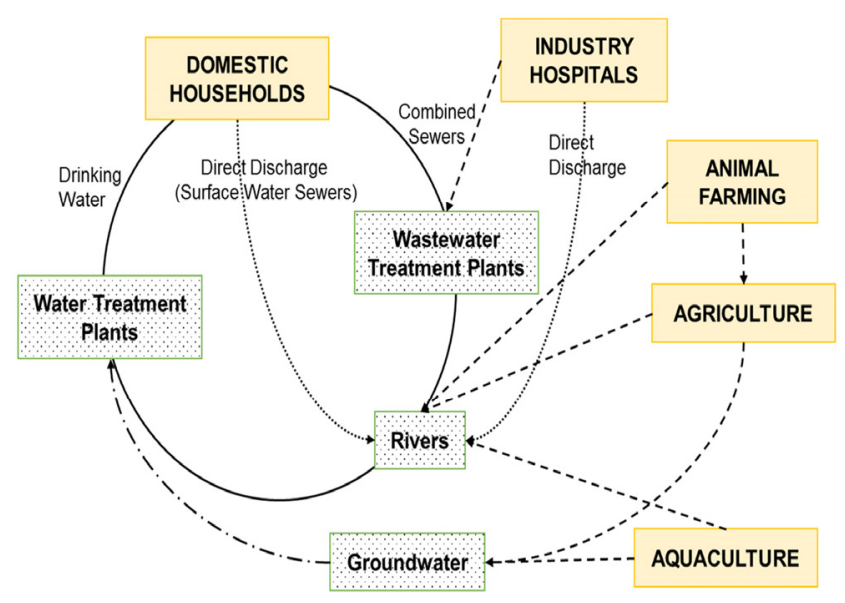

Fig. 1. Sources and pathways of PPCPs in the urban water cycle [22].
The physical properties of micropollutant can affect the movement of contaminants from one stage to another (e.g., soil-water movement). The mobility of the compounds is determined by transport/retention factors which are dependent on chemical related properties such as acid dissociation constant $\left(\mathrm{pK}_{\mathrm{a}}\right)$ and octanol-water partition coefficient $\left(\mathrm{K}_{\mathrm{ow}}\right)$. Adsorption, precipitation, complex formation and colloid formation all contribute to the retention of micropollutants in water. Transport mechanisms include advection, dispersion, diffusion and active transport.

Physical property of micropollutant can affect the movement of pollutants from one phase to another (e.g., soil-water transfer). The mobility of the compounds is determined by transportation/retention factors, which depend on chemical-related properties such as the logarithmic acid dissociation constant $\left(\mathrm{pK}_{\mathrm{a}}\right)$ and the octanol-water partitioning coefficient $\left(\mathrm{K}_{\mathrm{ow}}\right)$. Sorption, precipitation, complexation, and colloid formation all contribute to the retention of micropollutants in water. Mechanisms of transport include advection, dispersion, diffusion, and active transport.

Transformation processes, that is, the decomposition of the parent compound as a byproduct, does not completely prevent the micropollutants from reaching the natural environment. Unless appropriate conversion processes are applied in the wastewater treatment process, it is difficult to control the amount of miropollutants to be emitted and accumulation may occur in the aquatic environment.

\section{Occurrence of Micropollutants in Water}

The presence of micropollutants in surface water has recently been widely reported. WWTPs can discharge wastewater effluent containing untreated micropollutants directly into rivers, lakes, rivers and reservoirs. Emitted micropollutants can be naturally deposited on sediments or transported to other places due to hydrological impact. These compounds can also be simultaneously converted to by-products by chemical and biological degradation at surface water [24]. However, at least some micro-contaminants are likely to persist and accumulate in surface waters [25].

Table 1 shows the concentrations of micropollutants in surface water, ground water, sewage treatment plant (STP) influents or effluents, WWTP influents or effluents, and hospital effluents. These results indicate that micropollutants have been ubiquitous pollutants in water environment.

In most countries, surface water is the source of drinking water in an area of increasing urban population in general. Therefore, micropollutants in surface waters can enter WTPs, and their presence in drinking water has been reported by several researchers. For example, clofibric acid has been reported at high concentrations (> $165 \mathrm{ng} / \mathrm{L}$ ) in tap water in Berlin [61]. People can be unconsciously exposed to these micropollutants through tap water used for drinking, cooking and bathing. Therefore, removal of micropollutant by WTP is important for drinking water production. However, the presence of micropollutant present in tap water means that existing water treatment systems can not completely remove micro-contaminants from WTP. 
Table 1. Distributions of the Micropollutants in Various Water Matrixes

\begin{tabular}{|c|c|c|c|c|}
\hline Compounds & Water sample & Country & Concentration (ng/L) & References \\
\hline \multirow[t]{10}{*}{ acetaminophen } & surface water & Serbia & 78,170 & {$[26]$} \\
\hline & surface water & Korea & $5-127$ & {$[27]$} \\
\hline & surface water & Korea & 4.1-7.3 & {$[6]$} \\
\hline & ground water & USA & 380 & {$[28]$} \\
\hline & STP influent & Korea & $13,406-56,944$ & {$[27]$} \\
\hline & STP influent & Spain & $24,600-29,000$ & {$[29]$} \\
\hline & STP effluent & Korea & $5-9$ & {$[27]$} \\
\hline & STP effluent & Korea & 1.9-19 & {$[6]$} \\
\hline & STP effluent & Spain & $32-4,300$ & [29] \\
\hline & hospital effluent & Taiwan & 62,250 & {$[30]$} \\
\hline \multirow[t]{15}{*}{ caffeine } & surface water & Germany & $65-6,798$ & {$[31]$} \\
\hline & surface water & Denmark & $65-382$ & {$[32]$} \\
\hline & surface water & China & 339 & [33] \\
\hline & surface water & Korea & $0-373$ & {$[27]$} \\
\hline & ground water & Europe & 189 & [31] \\
\hline & ground water & USA & 290 & {$[34]$} \\
\hline & WWTP influent & Greece & $17,100-113,200$ & [35] \\
\hline & WWTP influent & Taiwan & $5,173-17,500$ & [30] \\
\hline & WWTP influent & USA & 26,567 & {$[36]$} \\
\hline & WWTP effluent & Korea & 3,600 & [37] \\
\hline & WWTP effluent & Korea & $19-873$ & {$[27]$} \\
\hline & WWTP effluent & Korea & $23-776$ & {$[6]$} \\
\hline & WWTP effluent & Taiwan & $19-1,727$ & [30] \\
\hline & WWTP effluent & USA & 28 & {$[36]$} \\
\hline & WWTP effluent & Greece & $1,900-13,900$ & {$[35]$} \\
\hline \multirow[t]{9}{*}{ carbamazepine } & surface water & Korea & $4.5-61$ & {$[6]$} \\
\hline & surface water & Korea & $<595$ & [38] \\
\hline & surface water & Korea & $5-36$ & [27] \\
\hline & surface water & USA & 6.8 & [39] \\
\hline & STP influent & Korea & $5-451$ & {$[27]$} \\
\hline & STP effluent & Korea & $73-729$ & {$[6]$} \\
\hline & STP effluent & Sweden & 1,680 & {$[40]$} \\
\hline & STP effluent & Japan & $10.8-163$ & {$[41]$} \\
\hline & hospital effluent & Spain & $30-70$ & [29] \\
\hline \multirow[t]{9}{*}{ diclofenac } & surface water & Korea & $8.8-127$ & {$[6]$} \\
\hline & surface water & China & $<147$ & {$[42]$} \\
\hline & surface water & Sweden & $10-120$ & {$[40]$} \\
\hline & surface water & UK & $20-91$ & [43] \\
\hline & STP influent & UK & $350-460$ & {$[43]$} \\
\hline & STP effluent & Korea & $8.8-127$ & {$[6]$} \\
\hline & STP effluent & Sweden & 120 & {$[40]$} \\
\hline & STP effluent & Spain & $200-3,600$ & [29] \\
\hline & hospital effluent & Taiwan & 328 & {$[30]$} \\
\hline \multirow[t]{8}{*}{ ibuprofen } & surface water & Korea & $11-38$ & {$[6]$} \\
\hline & surface water & Germany & $60-152$ & {$[44]$} \\
\hline & surface water & Korea & $5-414$ & [38] \\
\hline & ground water & USA & 3,110 & [47] \\
\hline & STP influent & Spain & $37-860$ & {$[44]$} \\
\hline & STP influent & Taiwan & 711-17,933 & {$[30]$} \\
\hline & STP effluent & Korea & 10-137 & {$[6]$} \\
\hline & STP effluent & Taiwan & $313-3,777$ & [30] \\
\hline
\end{tabular}




\begin{tabular}{|c|c|c|c|c|}
\hline Compounds & Water sample & Country & Concentration (ng/L) & References \\
\hline \multirow[t]{3}{*}{ metoprolol } & surface water & Spain & 90 & [12] \\
\hline & surface water & China & 24.8 & {$[48]$} \\
\hline & WWTP effluent & Sweden & 274 & [48] \\
\hline \multirow[t]{10}{*}{ naproxen } & surface water & Sweden & $90-250$ & {$[40]$} \\
\hline & surface water & China & $<118$ & {$[42]$} \\
\hline & surface water & Germany & 70 & {$[44]$} \\
\hline & surface water & Korea & $20-483$ & {$[6]$} \\
\hline & STP influent & Sweden & 3,650 & {$[40]$} \\
\hline & STP influent & Spain & $109-455$ & {$[44]$} \\
\hline & STP influent & Japan & $38-230$ & {$[41]$} \\
\hline & STP effluent & Sweden & 250 & {$[40]$} \\
\hline & STP effluent & Japan & $12-139$ & {$[41]$} \\
\hline & STP effluent & Belgium & 625 & {$[44]$} \\
\hline \multirow[t]{10}{*}{ sulfamethoxazole } & surface water & Korea & $1.7-36$ & {$[6]$} \\
\hline & surface water & Korea & $5-82$ & [27] \\
\hline & surface water & USA & 150 & {$[45]$} \\
\hline & surface water & USA & $<300$ & {$[46]$} \\
\hline & ground water & USA & 1,110 & {$[47]$} \\
\hline & STP influent & USA & $<1,000$ & {$[46]$} \\
\hline & STP influent & Korea & $156-984$ & [27] \\
\hline & STP effluent & USA & 310 & {$[46]$} \\
\hline & STP effluent & Korea & $3.8-407$ & {$[6]$} \\
\hline & hospital effluent & Taiwan & 1,335 & {$[30]$} \\
\hline \multirow[t]{3}{*}{ sulfamethazine } & ground water & USA & 360 & {$[47]$} \\
\hline & STP influent & Korea & 132 & [49] \\
\hline & STP effluent & Korea & 114 & [49] \\
\hline \multirow[t]{7}{*}{ atrazine } & surface water & USA & $4.7-3,600$ & {$[50]$} \\
\hline & surface water & Korea & 1.8-18 & {$[51]$} \\
\hline & ground water & Europe & 8 & [52] \\
\hline & ground water & Switzerland & $1-179$ & {$[53]$} \\
\hline & STP influent & Switzerland & $52-59$ & [53] \\
\hline & WWTP effluent & Spain & 124 & {$[54]$} \\
\hline & WWTP effluent & Switzerland & $25-34$ & [53] \\
\hline \multirow[t]{7}{*}{ bisphenol-A } & surface water & USA & 81 & {$[50]$} \\
\hline & surface water & Korea & $4.5-61$ & [51] \\
\hline & surface water & Europe & 10 & {$[50]$} \\
\hline & surface water & Germany & $28-68$ & {$[31]$} \\
\hline & surface water & USA & 6,000 & [39] \\
\hline & STP effluent & UK & 19.2 & {$[55]$} \\
\hline & WWTP effluent & USA & $281-3,642$ & {$[55]$} \\
\hline \multirow[t]{4}{*}{$2,4-\mathrm{D}$} & surface water & China & $5.6-6.2$ & {$[42]$} \\
\hline & ground water & Europe & $<12$ & [52] \\
\hline & STP effluent & Spain & 33.4 & {$[56]$} \\
\hline & STP effluent & Spain & 21.4 & {$[56]$} \\
\hline \multirow[t]{7}{*}{ triclosan } & surface water & USA & $9-1,550$ & {$[57]$} \\
\hline & surface water & USA & $4.6-55$ & [57] \\
\hline & surface water & USA & $3.3-41$ & {$[57]$} \\
\hline & surface water & USA & 8.8-75 & [57] \\
\hline & surface water & USA & $10-2,230$ & [58] \\
\hline & surface water & USA & $10-600$ & [58] \\
\hline & surface water & USA & $0.45-486$ & [58] \\
\hline
\end{tabular}




\begin{tabular}{|c|c|c|c|c|}
\hline Compounds & Water sample & Country & Concentration (ng/L) & References \\
\hline \multirow[t]{5}{*}{ nonylphenol } & surface water & USA & 800 & {$[45]$} \\
\hline & surface water & Korea & $23.2-187.6$ & {$[59]$} \\
\hline & surface water & China & $1,900-32,800$ & {$[60]$} \\
\hline & STP influent & Japan & $500-1,100$ & {$[41]$} \\
\hline & STP effluent & Japan & $100-900$ & [41] \\
\hline
\end{tabular}

STP: Sewage Treatment Plant; WWTP: Waste Water Treatment Plant

Table 2. Human Toxicological Values of Micropollutants in Drinking Water

\begin{tabular}{|c|c|c|}
\hline Compounds & Toxicological data (taxon, effect) & References \\
\hline diclofenac & $\begin{array}{l}\text { Maximum oral exposure: } 4 \mu \mathrm{g} / \mathrm{d}, 36 \text { weeks } \\
\text { (Pregnant women, Premature closure of the ducts arteriosus or hemodynamic changes }\end{array}$ & {$[62]$} \\
\hline carbamazepine & $\begin{array}{l}\text { Provisional guideline value }=1 \mu \mathrm{g} / \mathrm{L}, 24 \text { mon (Rats, Carcinogenetic) } \\
\text { Maximum concentration in drinking water: } 0.03 \mu \mathrm{g} / \mathrm{L} \\
\text { Benchmark quotient: } 0.03 / 1=0.03\end{array}$ & [63] \\
\hline ibuprofen & $\begin{array}{l}\text { Maximum oral exposure }=24 \mu \mathrm{g} / \mathrm{d}, 36 \text { weeks } \\
\text { (Pregnant women, Premature closure of the ducts arteriosus or hemodynamic changes) }\end{array}$ & [63] \\
\hline metoprolol & $\begin{array}{l}\text { Provisional guideline value }=50 \mu \mathrm{g} / \mathrm{L} \text { (Diabetic patients, hypoglycemia) } \\
\text { Maximum concentration in drinking water: } 2.1 \mu \mathrm{g} / \mathrm{L} \\
\text { Benchmark quotient: } 2.1 / 50=0.04\end{array}$ & [63] \\
\hline sulfamethoxazole & $\begin{array}{l}\text { Provisional guideline value }=440 \mu \mathrm{g} / \mathrm{L}, 60 \text { weeks (Rats, thyroid tumors) } \\
\text { Maximum concentration in drinking water: } 0.03 \mu \mathrm{g} / \mathrm{L} \\
\text { Benchmark quotient: } 0.03 / 440=0.00007\end{array}$ & [63] \\
\hline
\end{tabular}

Table 3. Water Quality Standards for the Micropollutants in Environmental Agencies

\begin{tabular}{|c|c|c|c|}
\hline Compounds & Country & Standards $(\mu \mathrm{g} / \mathrm{L})$ & References \\
\hline \multirow[t]{5}{*}{ atrazine } & International & $<100$ & [64] \\
\hline & USA & $<3$ & [65] \\
\hline & Canada & $<5$ & [66] \\
\hline & Australia & $<20$ & [67] \\
\hline & Europe & $<0.6^{*}$ & [68] \\
\hline \multirow[t]{4}{*}{$2,4-\mathrm{D}$} & International & $<30$ & [64] \\
\hline & USA & $<70$ & [65] \\
\hline & Canada & $<100$ & [66] \\
\hline & Australia & $<30$ & [67] \\
\hline diclofenac & Europe & $<0.1^{*}$ & [69] \\
\hline nonylphenol & Europe & $<0.3^{*}$ & [69] \\
\hline $17 \alpha$-ethinylestradiol & Europe & $<0.000035^{*}$ & [69] \\
\hline 17ß-estradiol & Europe & $<0.0004^{*}$ & [69] \\
\hline
\end{tabular}

"This value is the Environmental quality standard (EQS) expressed as an annual average value (i.e., AA-EQS) in inland surface water. Here, "inland surface water" means the rivers and lakes and related artificial or heavily modified water bodies.

\section{Human Health Impact of Micropollutants in Water}

Pharmaceuticals among micropollutants raised concerns about the effects of unintended exposure to humans and ecosystems. When considering the food chain, these exposures can cause persistent bioaccumulation in the ecosystem. Chronic exposure to the human body can cause potentially unknown health effects. Previous studies reported health risks to humans through chronic pharmaceutical exposure in drinking water (Table 2).

Contamination of micropollutants can have a potentially negative effect on human health. The health effects of trace micropollutants are not clear, but people can increase their negative attitudes towards reused tap water. Because micropollutants are emerging issues in public health, water quality standards and guidelines are needed to provide safe drinking water to people. The criteria for these micropollutants are currently set in a number of countries, such as the United States, Canada, the European Union and Australia, although the levels of water quality standards are currently quite different (Table 3). 


\section{Removal of Micropollutants in WTPs}

Several studies have estimated the removal rate of micropollutants by WTP (Table 4). Gibs et al. [70] evaluated the removal of 113 contaminants during clotting/sedimentation, sand filtration and chlorination. Acetaminophen, diclofenac and sulfamethiazine showed high removal rate ( $>95 \%)$ after the water treatment process. However, the removal rate was low for micropollutants such as caffeine, carbamazepine, and bisphenol-A. Recently, Nam et al. [71] reported that the removal efficiencies of micropollutants detected in a WTP ranged from $6 \%$ to $100 \%$. Diclofenac, acetaminophen, caffeine, carbamazepine, and 2,4-D were effectively removed ( $>80 \%$ ), whereas only small amounts of metoprolol (6\%) were removed in the WTP process.

Removal rates of micropollutants are inconsistent among different studies [10, 39, 72]. In particular, caffeine ( 42-99\%), carbamazepine ( $\sim 46-99 \%)$, atrazine ( $\sim 53-99 \%)$, and bisphenol A ( 78-99\%) have shown both high and low removal rates by WTPs, because there are often differences among plants in terms of measurement method, and process configuration (Table 4).

Table 4. Removals of Micropollutants in Water Treatment Plants

\begin{tabular}{|c|c|c|c|c|}
\hline Compounds & Influent (ng/L) & Effluent (ng/L) & Removal (\%) & References \\
\hline \multicolumn{5}{|l|}{ Pharmaceuticals } \\
\hline \multirow[t]{3}{*}{ acetaminophen } & $120-150$ & $0-0.3$ & 98 & {$[73]$} \\
\hline & $163-260$ & $10.7-22$ & $94-98$ & {$[74]$} \\
\hline & $106.1 \pm 147.1$ & $5 \pm 9.1$ & 95.3 & {$[71]$} \\
\hline \multirow[t]{5}{*}{ caffeine } & 100-190 & ND-60 & $42-99$ & {$[73]$} \\
\hline & 100,000 & ND-119 & 88-99 & {$[10]$} \\
\hline & 45 & ND & 99 & {$[6]$} \\
\hline & $291-526$ & ND-27.7 & $93-101$ & {$[74]$} \\
\hline & $36.1 \pm 20.8$ & $5.8 \pm 7.4$ & 84 & {$[71]$} \\
\hline \multirow[t]{4}{*}{ carbamazepine } & 13 & - & 99 & {$[12]$} \\
\hline & $4.1-51$ & $6-18$ & $-46-88$ & [39] \\
\hline & 4.8 & ND & 99 & {$[6]$} \\
\hline & $10.3 \pm 9.5$ & $1.7 \pm 4.2$ & 84.7 & {$[71]$} \\
\hline \multirow[t]{3}{*}{ diclofenac } & 1.1-1.2 & ND & 99 & [39] \\
\hline & $175-292$ & ND & 98.8-99.2 & {$[74]$} \\
\hline & $7.8 \pm 2.45$ & ND & 100 & {$[71]$} \\
\hline \multirow[t]{2}{*}{ ibuprofen } & 15 & ND & 99 & {$[6]$} \\
\hline & $19.6 \pm 21$ & $4.3 \pm 6$ & 78 & {$[71]$} \\
\hline \multirow[t]{2}{*}{ metoprolol } & 68.7 & 60 & 11 & {$[75]$} \\
\hline & $37.4 \pm 34.1$ & $35.18 \pm 22.4$ & 6 & {$[71]$} \\
\hline \multirow[t]{3}{*}{ naproxen } & $0.9-32$ & ND & 99 & [39] \\
\hline & $99-152$ & ND & $98.8-99.2$ & {$[74]$} \\
\hline & $11.8 \pm 12.4$ & $2.7 \pm 3.8$ & 78 & {$[71]$} \\
\hline \multirow[t]{4}{*}{ sulfamethoxazole } & 30 & ND & 99 & {$[73]$} \\
\hline & 8,000 & ND & 99 & {$[10]$} \\
\hline & $57.7-149$ & ND & $98-100$ & {$[74]$} \\
\hline & $7.8 \pm 5.4$ & $2.1 \pm 1.9$ & 73 & {$[71]$} \\
\hline \multirow[t]{2}{*}{ sulfamethazine } & 113 & ND & $98-100$ & {$[74]$} \\
\hline & $3.7 \pm 2.4$ & $2.31 \pm 1.7$ & 38 & {$[71]$} \\
\hline \multicolumn{5}{|l|}{ Endocrine disrupters } \\
\hline \multirow[t]{2}{*}{ atrazine } & $32-870$ & $49-870$ & -53 & [39] \\
\hline & 7 & ND & 99 & {$[72]$} \\
\hline \multirow[t]{3}{*}{ bisphenol-A } & $6.1-14$ & 25 & -78 & [39] \\
\hline & 295 & 5 & 98.3 & {$[72]$} \\
\hline & $88 \pm 102.8$ & $5 \pm 9.1$ & 95.3 & {$[71]$} \\
\hline \multirow[t]{2}{*}{ nonylphenol } & 100-130 & $93-100$ & 7 & [39] \\
\hline & $14.5 \pm 52.1$ & $12.6 \pm 5.9$ & 70 & {$[71]$} \\
\hline
\end{tabular}

ND: Not detected 


\section{Removal of Micropollutants by Each Water Treatment process}

\subsection{Coagulation/Sedimentation}

Coagulation removes particulate matter, including colloidal and dissolved substances, from water. Chemical coagulation is the main process to remove suspended solids by the addition of coagulants to change the electrostatic state of contaminants [76, 77]. Natural particles, such as clay and natural organic matter (NOM), can be negatively charged to water and electrostatically interact [78]. Natural particles such as clays, and NOM are negatively charged in water, and can therefore interact electrostatically [78]. Small particles and NOM suspended in natural water are too small to precipitate out of surface water. Positively charged metal salts (often aluminum and iron salts) are often used as coagulants. Their efficacy is influenced by $\mathrm{pH}[76,79]$. The metal salt binds to suspended particles in water via electro-neutralization at $\mathrm{pH}$ 5-7 [80-82]. Charge neutralization causes floc formation and these aggregation products bind to each other via van der Waals forces (i.e., sweep flocculation). These mechanisms can separate water and NOM from water.

Several previous studies have evaluated the removal of micropollutants by coagulation, using jar tests among other methods. Table 6 summarizes the removals of micropollutants during coagulation processes. In a study by Matamoros and Salvadó [83], micropollutant removal via coagulation ranged from imperceptible elimi- nation to $50 \%$, with relatively high removals (20-50\%) observed for compounds with a $\mathrm{K}_{\text {ow }}$ of 4 at $\mathrm{pH} \sim 7-8$ (e.g., galaxolide, tonalide, and octylphenol). Suárez et al. [84] reported significant reduction $(\sim 80 \%)$ of musks (e.g., galaxolide and tonalide) during hospital wastewater coagulation treatment. Other micropollutants have shown similar rates of elimination (diclofenac, max. 46\%; naproxen, max. 42\%; and ibuprofen, max. 23\%). Asakura and Matsuto [85] found that biphenol-A could not be removed by coagulation and sedimentation, but that high removal rates for DEHP and nonylphenol (70\% and 90\%, respectively) were achieved through leachate treatment.

The efficiency of micropollutant removal by coagulation varies depending on conditions such as $\mathrm{pH}$, coagulant type and dose (Table 5). Most micropollutants had low elimination rates $(<50 \%)$ by coagulation. However, some studies have reported an electrostatic interaction between coagulants and micropollutants. Hydrophilic micropollutants such as acetaminophen $\left(\log \mathrm{K}_{\mathrm{ow}}=\right.$ 0.46), sulfamethoxazole ( $\log K_{\mathrm{ow}}=0.68$ ) and sulfamethazine (log $\left.\mathrm{K}_{\mathrm{ow}}=0.62\right)$ can be electrically aggregated with $\mathrm{Al}^{3+}$ or $\mathrm{Fe}^{3+}$ ions in the coagulants [71, 73]. Especially, due to $\mathrm{pK}_{\mathrm{a}}$ values (SMZ $=5.7$, SMA $\left.=2.6\left(\mathrm{pK}_{\mathrm{a} 1}\right) / 7.7\left(\mathrm{pK}_{\mathrm{a} 2}\right)\right)$, sulfamethoxazole and sulfamethazine exist as negative ions at neutral $\mathrm{pH}$, therefore, these compounds can be effectively coagulated to $\mathrm{Al}^{3+}$ ion of $\mathrm{PACl}$ (polyalumium chloride) during coagulation process. Antibiotics, such as tetracycline antibiotics (log $\mathrm{K}_{\mathrm{ow}}<-1.37$ ), have been removed at rates of $\sim 43-94 \%$ via the coagulation process [86]. These results indicate that electrical aggregation is an important mechanism in the coagulation step.

Table 5. Removal Efficiencies of Some Micropollutants by Coagulation (modified from Luo et al. [87])

\begin{tabular}{|c|c|c|c|c|}
\hline Coagulant & $\begin{array}{c}\text { Dosage with } \mathrm{pH} \text { value presented in the } \\
\text { parentheses }\end{array}$ & Compound & Removal (\%) & References \\
\hline \multirow[t]{7}{*}{$\mathrm{FeCl}_{3}$} & $25,50 \mathrm{mg} / \mathrm{L}(7)$ & ibuprofen & $12.0 \pm 4.8$ & {$[84]$} \\
\hline & & diclofenac & $21.6 \pm 19.4$ & \\
\hline & & naproxen & $21.8 \pm 10.2$ & \\
\hline & & carbamazepine & $6.3 \pm 15.9$ & \\
\hline & & sulfamethoxazole & $6.0 \pm 9.5$ & \\
\hline & & trimethoprim & $32.1 \pm 51.1$ & \\
\hline & & galazxolide & $79.2 \pm 9.9$ & \\
\hline \multirow[t]{4}{*}{$\mathrm{Al}_{2}\left(\mathrm{SO}_{4}\right)_{3}$} & $25 \mathrm{mg} / \mathrm{L} \mathrm{(7)}$ & diazepam & $12.5 \pm 18.4$ & {$[84]$} \\
\hline & & sulfamethoxazole & $0.9 \pm 14.4$ & \\
\hline & & tonalide & $75.8 \pm 11.0$ & \\
\hline & & galazxolide & $76.4 \pm 5.5$ & \\
\hline \multirow[t]{3}{*}{$\mathrm{FeCl}_{3}$} & 100, $200 \mathrm{mg} / \mathrm{L}(4,7,9)$ & bisphenol-A & 20 & \\
\hline & & diethylhexylphthalate & 70 & [85] \\
\hline & & nonylphenol & 90 & \\
\hline \multirow[t]{2}{*}{$\mathrm{Al}_{2}\left(\mathrm{SO}_{4}\right)_{3}$} & 200 mg/L (7) & aldrin & 46 & [88] \\
\hline & 100 mg/L (7) & bentazon & 15 & \\
\hline \multirow[t]{6}{*}{ PACl } & 30 mg/L (7) & sulfamethoxazole & 43 & {$[71]$} \\
\hline & & sulfamethazine & 52 & \\
\hline & & caffeine & 16 & \\
\hline & & acetaminophen & 17 & \\
\hline & & diclofenac & 0 & \\
\hline & & metoprolol & 10 & \\
\hline
\end{tabular}


Other removal mechanisms (e.g., particle adsorption and sunlight photolysis) can be used during the coagulation process to enhance micropollutant removal. Hydrophobic compounds can be adsorbed into suspended particles, and co-removed through coagulation/sedimentation processes [89]. Higher removal efficiencies for acetaminophen (76.6\% with the concentrations of 24.7 $\pm 43.3 \mathrm{ng} / \mathrm{L})$, caffeine $(81.2 \%$ with the concentrations of $6.7 \pm$ $10.5 \mathrm{ng} / \mathrm{L}$ ), and diclofenac (100\% with the concentration of less than the method detection limit), which are photo-sensitives, have been observed during the WTP coagulation process [71]. This result implies that sunlight photo-degradation can be an additional mechanism for micropollutant removal, because coagulation occurs in the open air; these mechanisms can also act simultaneously.

\subsection{Adsorption}

Adsorption by activated carbons is commonly used to control the taste and odor of drinking water. Adsorbate and adsorbent interactions in adsorption involve complex surface reactions, hydrophobic interactions at the surface, and adsorption of surfactant or polymers and polyelectrolytes [90].

Several studies on the efficacy of micropollutant removal by adsorption have been done using lab- and pilot-scale experiments (Table 6). Powdered activated carbon (PAC) and granular activated carbon (GAC) have been widely used in adsorption processes, which can be affected by both adsorbate and adsorbent properties [91]. Micropollutant removal has been improved with increased PAC doses, independent of the initial compound concentrations [92]. Batch tests performed by Hernández-Leal et al. [92] demonstrated marked removal ( $>94 \%$ ) of various micropollutants (i.e., with effluent concentrations of $173 \mathrm{ng} / \mathrm{L}$ for caffeine and $9 \mathrm{ng} / \mathrm{L}$ for buthylparaben) using PAC adsorption, with initial compound concentrations of $\sim 100-1,600$ $\mu \mathrm{g} / \mathrm{L}$ at a dose of $1.25 \mathrm{~g} / \mathrm{L}$ and a contact time of $5 \mathrm{~min}$.

Table 6. Removal Efficiencies of Some Micropollutants by Adsorption (modified from Luo et al. [87])

\begin{tabular}{|c|c|c|c|c|}
\hline Adsorbent & Dosage & Compound & Removal (\%) & References \\
\hline \multirow[t]{12}{*}{ PAC } & $8,23,43 \mathrm{mg} / \mathrm{L}$ & diclofenac & $96,98,99$ & [91] \\
\hline & & carbamazepine & $98,99,100$ & \\
\hline & & sulfamethoxazole & $2,33,62$ & \\
\hline & $100 \mathrm{mg} / \mathrm{L}$ & caffeine & $>94$ & \\
\hline & & bisphenol-A & $>94$ & [92] \\
\hline & & nonylphenol & $>94$ & \\
\hline & $5 \mathrm{mg} / \mathrm{L}$ & acetaminophen & $70-79$ & [93] \\
\hline & & caffeine & $60-62$ & \\
\hline & & diclofenac & $30-57$ & \\
\hline & & naproxen & $52-57$ & \\
\hline & & sulfamethoxazole & $30-37$ & \\
\hline & & atrazine & $55-57$ & \\
\hline \multirow[t]{20}{*}{ GAC } & Full scale & diclofenac & $>98$ & [94] \\
\hline & & carbamazepine & 23 & \\
\hline & & estrone & 64 & \\
\hline & & 17ß-estradiol & $>43$ & \\
\hline & & 17 $\alpha$-ethinylestradiol & $>43$ & \\
\hline & $29 \mathrm{~g} / 70.6 \mathrm{~mL}$ bed volume & bisphenol-A & 66 & \\
\hline & & nonylphenol & 84 & [92] \\
\hline & & triclosan & 95 & \\
\hline & Full scale, empty bed contact time:15 min & diclofenac & $\sim 100$ & [95] \\
\hline & & trimethoprim & 90 & \\
\hline & & carbamazepine & 75 & \\
\hline & & caffeine & 45 & \\
\hline & $1 \mathrm{mg} / \mathrm{L}$ & acetaminophen & 58 & [96] \\
\hline & & caffeine & 71.3 & \\
\hline & & atrazine & 53 & \\
\hline & & carbamazepine & 69.9 & \\
\hline & & diclofenac & 25.5 & \\
\hline & & ibuprofen & 23.3 & \\
\hline & & naproxen & 46.6 & \\
\hline & & sulfamethoxazole & 27.1 & \\
\hline
\end{tabular}

PAC: Powdered activated carbon; GAC: Granular activated carbon 
Interestingly, sorption coefficients of hydrophilic compounds (i.e., caffeine, acetaminophen, sulfamethoxazole, and sulfamethazine) have been shown to fit a linear isotherm, while hydrophobic compounds (i.e., naproxen, diclofenac, 2,4-D, triclocarban, and atrazine) fit a Freundlich isotherm [79]. In this study, it was found that the removal of hydrophobic pollutants and caffeine was independent of $\mathrm{pH}$ changes, but acetaminophen, sulfamethazine, and sulfamethoxazole were adsorbed mainly by electrostatic interaction with PAC; therefore, they were affected by $\mathrm{pH}$. Adsorption removal in surface water samples was decreased; this decrease was significant for hydrophobic compounds. The decline in adsorption capacity in surface water samples was caused by the competitive inhibition of dissolved organic matter (DOM) with micropollutants into PAC. Low temperature $\left(5^{\circ} \mathrm{C}\right)$ also decreased the adsorption removal of micropollutants, and affected hydrophobic compounds more than hydrophilic compounds.

As the elimination of trace contaminants depends largely on particle-contaminant interactions, competition for adsorption sites and/or pore blocking (by particle solids) can reduce the removal efficiency of activated carbon [97]. Snyder et al. [93] suggested that a steam-treated GAC could be employed to overcome the drawbacks of GAC, due to its greater absorption capacity. Regular regeneration of GAC also seemed of vital importance to maintain minimal breakthrough of micropollutants. Furthermore, pore shape/size and volumes of activated carbons, as well as carbon type, surface charge of compounds, and operation year, influenced removal performances [27, 96].

\subsection{Chlorination}

Drinking water purification generally involves antibacterial treatment such as chlorination, ozone treatment $\left(\mathrm{O}_{3}\right)$ and ultraviolet (UV-C) to prevent the spread of waterborne diseases. This technique is effective in removing pathogens (> 99\%) from WTPs [98-101]. Chlorination is a disinfection process commonly used by WTP in some regions, including Korea.

Chlorination is generally not recognized as an organic contaminant removal process, but it can degrade organic contaminants through the oxidation of free chlorine [101, 102]. Chlorine molecules showed higher reactivity to aromatic pharmaceuticals and higher electrical affinity for certain functional groups of micropollutant. Chlorination is more cost-effective than other technologies (e.g., ozonation and ultraviolet light) because it is easy to perform [104]. However, since degradation by chlorination is too slow (e.g., sulfamethoxazole, acetaminophen, caffeine, and ibuprofen), chlorination is less effective (less than 20\%) to remove trace amounts of micropollutants [105, 106]. Production of harmful byproducts (e.g., trihalomethane (THM), haloacetic acid, haloacetonitrile) from drinking water chlorination has been a major concern, and chlorinated disinfection byproducts are considered as emerging contaminants that require elimination by WTPs [107, 108].

\subsection{Ozonation}

The main reasons for applying ozone to drinking water treatment are disinfection and oxidation (e.g., taste and odor control, de-coloration, elimination of micropollutants, etc.) or a combination of both [109, 110]. Ozonation can oxidize micropollutants either by a direct reaction with ozone or indirectly after formation of hydroxyl radicals, as follows in Table 7 .

Table 7. Ozonation Processes with Micropollutants (modified from von Gunten [109, 110] and Šojić et al. [111])

\begin{tabular}{|c|c|}
\hline Ozonation & Reference \\
\hline directly reaction & {$[109,110]$} \\
\hline $\mathrm{O}_{3}+$ Contaminants $\rightarrow$ End products & \\
\hline $\mathrm{O}_{3}+$ Contaminants $\rightarrow$ Contaminants ${ }^{\cdot+}+\mathrm{O}_{3}^{\cdot-}$ & \\
\hline indirectly reaction & \\
\hline $\mathrm{H}_{2} \mathrm{O} \rightleftarrows \mathrm{H}^{+}+\mathrm{OH}^{-}$ & {$[109,111]$} \\
\hline $\mathrm{O}_{3}+\mathrm{OH}^{-} \rightarrow \mathrm{HO}_{2}^{-}+\mathrm{O}_{2}$ & \\
\hline $\mathrm{O}_{3}+\mathrm{HO}_{2}^{-} \rightarrow \cdot \mathrm{OH}+\mathrm{O}_{2}^{--}+\mathrm{O}_{2}$ & \\
\hline $\mathrm{O}_{3}+\mathrm{O}_{2}^{\cdot-} \rightarrow \mathrm{O}_{3}^{\cdot-}+\mathrm{O}_{2}$ & \\
\hline Contaminants $+\cdot \cdot \mathrm{OH} \rightarrow$ Contaminants $-\mathrm{H}+\mathrm{H}_{2} \mathrm{O}$ & \\
\hline Contaminants $-\mathrm{H}+\cdot \mathrm{OH} \rightarrow$ End products & \\
\hline
\end{tabular}

\subsection{Advanced Oxidation Processes (AOPs)}

Various AOPs such as UV radiation, $\mathrm{UV} / \mathrm{Cl}_{2}$ and $\mathrm{UV} / \mathrm{O}_{3}$ have been attempted to remove micropollutants (Table 8). This process uses a radical species (e.g., chlorine radical ( $\left.{ }^{\circ} \mathrm{Cl}\right)$, hydroxyl radical ( $\left.{ }^{\circ} \mathrm{OH}\right)$, and ozonide radical ion $\left.\left(\mathrm{O}_{3}{ }^{--}\right)\right)$to degrade micropollutants by oxidation. The main removal mechanisms of these processes for micropollutants are shown in Table 8.

Table 8. Removal mechanisms of $\mathrm{O}_{3}, \mathrm{UV}, \mathrm{Cl}_{2} / \mathrm{UV}$, and $\mathrm{UV} / \mathrm{O}_{3}$ process for micropollutants removals

\begin{tabular}{|c|c|}
\hline Processes & References \\
\hline \multicolumn{2}{|l|}{$U V$ radiation (UV) } \\
\hline $\mathrm{H}_{2} \mathrm{O}+\mathrm{UV}-\mathrm{C} \rightarrow{ }^{\bullet} \mathrm{H}+{ }^{\bullet} \mathrm{OH}$ & {$[38,112]$} \\
\hline \multicolumn{2}{|l|}{ Contaminants $+{ }^{\circ} \mathrm{OH} \rightarrow$ Contaminants $-\mathrm{H}+\mathrm{H}_{2} \mathrm{O}$} \\
\hline \multicolumn{2}{|l|}{ Contaminants- $\mathrm{H}+{ }^{\circ} \mathrm{OH} \rightarrow$ End products } \\
\hline \multicolumn{2}{|l|}{ Chlorination- $U V$ radiation $\left(\mathrm{Cl}_{2} / \mathrm{UV}\right)$} \\
\hline $\mathrm{Cl}_{2}+\mathrm{H}_{2} \mathrm{O} \rightarrow \mathrm{HOCl}+\mathrm{HCl}$ & {$[113,114]$} \\
\hline \multicolumn{2}{|l|}{$\mathrm{HOCl}+\mathrm{UV}-\mathrm{C} \rightarrow{ }^{\circ} \mathrm{OH}+{ }^{\circ} \mathrm{Cl}$} \\
\hline \multicolumn{2}{|l|}{ Contaminants $+{ }^{\cdot} \mathrm{OH} \rightarrow$ End products $+\mathrm{H}_{2} \mathrm{O}$} \\
\hline \multicolumn{2}{|l|}{ Contaminants $+{ }^{\bullet} \mathrm{Cl} \rightarrow$ End products $+\mathrm{H}_{2} \mathrm{O}$} \\
\hline \multicolumn{2}{|l|}{$U V$ radiation-ozonation $\left(U V / O_{3}\right)$} \\
\hline $\mathrm{O}_{3}+h v \rightarrow \mathrm{O}_{2}+\mathrm{O}^{\bullet}$ & {$[111,115]$} \\
\hline \multicolumn{2}{|l|}{$\mathrm{O}^{\circ}+\mathrm{H}_{2} \mathrm{O} \rightarrow 2 \mathrm{HO}^{\bullet}$} \\
\hline \multicolumn{2}{|l|}{$\mathrm{O}_{3}+h v+\mathrm{H}_{2} \mathrm{O} \rightarrow \mathrm{O}_{2}+\mathrm{H}_{2} \mathrm{O}_{2}$} \\
\hline \multicolumn{2}{|l|}{$\mathrm{H}_{2} \mathrm{O}_{2}+h v \rightarrow 2 \mathrm{HO}^{\circ}$} \\
\hline \multicolumn{2}{|l|}{ Contaminants $+{ }^{\cdot} \mathrm{OH} \rightarrow$ Contaminants $-\mathrm{H}+\mathrm{H}_{2} \mathrm{O}$} \\
\hline Contaminants- $\mathrm{H}+{ }^{\circ} \mathrm{OH} \rightarrow$ End products & \\
\hline
\end{tabular}

Micropollutants are rapidly degraded from parent compounds to byproducts through continuous radical attack. Micropollutants rapidly degrade from parent compounds to their byproducts through continuous radical attacks. A study by Sui et al. [116], 
on the efficiency of ozonation for the removal of various micropollutants, showed that carbamazepine, diclofenac, indomethacin, and trimethoprim concentrations were reduced by more than $95 \%$ at an applied ozone dose of $5 \mathrm{mg} / \mathrm{L}$. A study conducted by Gerrity et al. [117] focused on the application of $\mathrm{O}_{3} / \mathrm{H}_{2} \mathrm{O}_{2}$ for removing a suite of micropollutants during water reclamation. This process had considerable removal efficiency ( $>90 \%$, with the concentrations of $<0.50 \sim<25 \mathrm{ng} / \mathrm{L}$ in the ozone effluents) for almost all of the target contaminants. Kim et al. [118] investigated the effects of UV (wavelength: $254 \mathrm{~nm}$ ) -based processes (UV and $\mathrm{UV} / \mathrm{H}_{2} \mathrm{O}_{2}$ ) to remove 41 micropollutants. While UV alone can only remove only a few compounds at a significant level ( $>90 \%$; e.g., ketoprofen, diclofenac and antipyrine), and macrolide has been observed to be ineffective removal ( $\sim 24-34 \%)$. In contrast, the addition of $\mathrm{H}_{2} \mathrm{O}_{2}$ $(7.8 \mathrm{mg} / \mathrm{L})$ in UV significantly improved the efficiency of the process and increased the removal efficiency to 90 for 39 out of 41 compounds.

Oxidation generally does not result in complete mineralization, but in many cases forms a transformed product with much lower biological activity than the parent compound [119-122]. Most organic compounds, including micropollutants, are converted to hydrophilic byproducts with similar or lower molecular weights [123-127]. Richardson et al. [128] reported that most conversion products formed during ozonation have found to contain oxygen in structures such as aldehydes, ketones, and carboxylic acids. In addition to the formation of the conversion products, other unwanted byproducts may be formed, such as bromate, which is a potential human carcinogen formed during the ozonation of the bromide-containing water by a complex mechanism involving both ozone and hydroxyl radicals [109, 110]. N-nitrosodimethylamine (NDMA) formation also has been reported during drinking-water ozonation [129, 130].

$\mathrm{UV} / \mathrm{H}_{2} \mathrm{O}_{2}$ oxidation is a promising drinking water production technology for the reduction of a wide range of organic pollutants and undesirable natural organic constituents [131-133]. Recent studies have reported that $\mathrm{UV} / \mathrm{H}_{2} \mathrm{O}_{2}$ can increase the formation of controlled trihalomethanes (THMs) and haloacetic acid (HAA) under certain conditions [134, 135], whereas medium-pressure UV at high fluence (as in AOPs) could destroy some NDMA precursors [136]. Chu et al. [137] investigated changes in haloacetamide formation and speciation attributed to UV, $\mathrm{H}_{2} \mathrm{O}_{2}$ or $\mathrm{UV} / \mathrm{H}_{2} \mathrm{O}_{2}$, followed by the application of free chlorine to quench any excess hydrogen peroxide and to provide residual disinfection. The results showed that $\mathrm{H}_{2} \mathrm{O}_{2}$ preoxidation alone resulted in diiodoacetamide formation in two iodide-containing waters and increased bromine utilization.

It has recently been reported that a combination of disinfectants with AOP can be used to remove contaminant micropollutants. Šojić et al. [111] showed that $84 \%$ of metoprolol was degraded using the $\mathrm{UV} / \mathrm{O}_{3}$ reaction. Recently, Nam et al. [114] have shown that the $\mathrm{UV} / \mathrm{Cl}_{2}$ process is effective in treating methoproprol by generating $\mathrm{OH}$ and $\mathrm{Cl}$ radicals. After the filtration step in WTPs, the UV/chlorination process can be used not only for disinfection purposes but also for the removal of micropollutants.

\section{Conclusions}

Micropollutants are discharged to surface water from untreated STP and WWTP wastewaters. Some micropollutants enter WTPs after being discharged into surface waters. Conventional WTP processes such as coagulation, precipitation, chlorination and adsorption can remove trace amounts of micropollutants. However, the removal efficiency varies depending on the physicochemical properties of the micropollutants. Alternatively, AOP can be applied to improve removal of micropollutants in WTPs. Although advanced treatment techniques have proven to be promising alternatives for the removal of micropollutants, there are two problems associated with the application; high operating costs and the formation of undesirable by-products. Thus, a comprehensive understanding of the fate and toxicity of microorganisms and their byproducts in surface water and drinking water is essential to effectively predict effects of micropollutants on the receiving environment.

\section{Acknowledgements}

This review was supported by the International Research \& Development Program of the National Research Foundation of Korea (NRF) funded by the Ministry of Science, ICT and future Planning (NRF-2014R1A2A1A11052928).

\section{References}

1. Clara M, Strenn B, Gans O, Martinez E, Kreuzinger N, Kroiss H. Removal of selected pharmaceuticals, fragrances an endocrine disrupting compounds in a membrane bioreactor and conventional wastewater treatment plants. Water Res. 2005;39: 4797-4807.

2. International Environment Forum: Micropollutants. [cited 20 August 2016]. Available from: http://iefworld.org/fr/spmicropollutant. htm.

3. Boyd GR, Reemtsma H, Grimm DA, Mitra S. Pharmaceuticals and personal care products (PPCPs) in surface and treated waters of Louisiana, USA and Ontario, Canada. Sci. Total Environ. 2003;311:135-149.

4. Snyder SA, Westerhoff P, Yoon Y, Sedlak DL. Pharmaceuticals, personal care products, and endocrine disruptors in water: implications for the water industry. Environ. Eng. Sci. 2003 ;20:449-469.

5. Chen M, Ohman K, Metcalfe C, Ikonomou MG, Amatya PL, Wilson J. Pharmaceuticals and endocrine disruptors in wastewater treatment effluents and in the water supply system of Calgary, Alberta, Canada. Water Qual. Res. J. Can. 2006;41:351-364.

6. Kim SD, Cho J, Kim IS, Vanderford BJ, Snyder SA. Occurrence and removal of pharmaceuticals and endocrine disruptors in South Korean surface, drinking, and waste waters. Water Res. 2007;41:1013-1021.

7. Kumar A, Chang B, Xagoraraki I. Human health risk assessment of pharmaceuticals in water: issues and challenges ahead. Int. J. Environ. Res. Public Health. 2010;7:3929-3953. 
8. Wille K, Noppe H, Verheyden K, et al. Validation and application of an LC-MS/MS method for the simultaneous quantification of 13 pharmaceuticals in seawater. Anal. Bioanal. Chem. 2010;397:1797-1808.

9. Capdeville MJ, Budzinski H. Trace-level analysis of organic contaminants in drinking waters and groundwaters. TrACTrend. Anal. Chem. 2011;30:586-606.

10. Stackelberg PE, Furlong ET, Meyer MT, Zaugg SD, Henderson AK, Reissman DB. Persistence of pharmaceutical compounds and other organic wastewater contaminants in a conventional drinking-water-treatment plant. Sci. Total Environ. 2004;329: 99-113.

11. Kim SC, Carlson K. Quantification of human and veterinary antibiotics in water and sediment using SPE/LC/MS/MS. Anal. Bioanal. Chem. 2007;387:1301-1315.

12. Huerta-Fontela M, Galceran MT, Ventura F. Occurrence and removal of pharmaceuticals and hormones through drinking water treatment. Water Res. 2011;45:1432-1442.

13. EU, 2008. European Union. Water framework directive 2008/105/EC. European parliament and of the council. [cited 20 August 2016]. Available from: http://eur-lex.europa.eu/ legal-content/EN/TXT/?uri=CELEX:32008L0105.

14. Canadian Environmental Protection Act, 1999. [cited 20 August 2016]. Available from: http://www.hc-sc.gc.ca/ewh-semt/pubs/ contaminants/psl2-lsp2/nonylphenol/index-eng.php.

15. Deblonde T, Cossu-Leguille C, Hartemann P. Emerging pollutants in wastewater: A review of the literature. Int. J. Hyg. Environ. Health. 2011;214:442-448.

16. Lapworth DJ, Baran N, Stuart ME, Ward RS. Emerging organic contaminants in groundwater: A review of sources, fate and occurrence. Environ. Pollut. 2012;163:287-303.

17. Verlicchi P, Al Aukidy M, Zambello E. Occurrence of pharmaceutical compounds in urban wastewater: Removal, mass load and environmental risk after a secondary treatment-a review. Sci. Total Environ. 2012;429:123-155.

18. Thomas PM, Foster GD. Tracking acidic pharmaceuticals, caffeine, and triclosan through the wastewater treatment process. Environ. Toxicol. Chem. 2005;24:25-30.

19. Poulsen PB, Jensen AA, Wallström E. More environmentally friendly alternatives to PFOS-compounds and PFOA. Environmental Project no.10132005. 2005.

20. Prevedouros K, Cousins IT, Buck RC, Korzeniowski SH. Sources, fate and transport of perfluorocarboxylates. Environ. Sci. Technol. 2006;40:32-44.

21. Sonnenschein C, Soto AM. An updated review of environmental estrogen and androgen mimics and antagonists. J. Steroid Biochem. Mol. Biol. 1998;65:143-150.

22. Ellis JB. Pharmaceutical and personal care products (PPCPs) in urban receiving waters. Environ. Pollut. 2006;144:184-189.

23. Caliman FA, Gavrilescu M. Pharmaceuticals, personal care products and endocrine disrupting agents in the environmentA review. CLEAN-Soil, Air, Water 2009;37:277-303.

24. Monteiro SC, Boxall ABA. Occurrence and fate of human pharmaceuticals in the environment. Rev. Environ. Contam. T. 2010;202:53-154.

25. Zhou J, Zhang Z, Banks E, Grover D, Jiang JQ. Pharmaceutical residues in wastewater treatment works effluents and their impact on receiving river water. J. Hazard. Mater. 2009;166: 655-661.

26. Grujić S, Vasiljević T, Laušević M. Determination of multiple pharmaceutical classes in surface and ground waters by liquid chromatography-ion trap-tandem mass spectrometry. J. Chromatogr. A. 2009;1216:4989-5000.

27. Choi K, Kim Y, Park J, et al. Seasonal variations of several pharmaceutical residues in surface water and sewage treatment plants of Han River, Korea. Sci. Total Environ. 2008;405:120-128.

28. Barnes KK, Kolpin DW, Furlong ET, Zaugg SD, Meyer MT, Barber LB. A national reconnaissance of pharmaceuticals and other organic wastewater contaminants in the United States-I) Groundwater. Sci. Total Environ. 2008;402:192-200.

29. Gómez MJ, Lacorte S, Fernández-Alba A, Agüera A. Pilot survey monitoring pharmaceuticals and related compounds in a sewage treatment plant located on the Mediterranean coast. Chemosphere 2007;66:993-1002.

30. Lin AYC, Tsai YT. Occurrence of pharmaceuticals in Taiwan's surface waters: Impact of waste streams from hospitals and pharmaceutical production facilities. Sci. Total Environ. 2009;407:3793-3802.

31. Loos R, Locoro G, Contini S. Occurrence of polar organic contaminants in the dissolved water phase of the Danube River and its major tributaries using SPE-LC-MS ${ }^{2}$ analysis. Water Res. 2010;44:2325-2335.

32. Matamoros V, Arias CA, Nguyen LX, Salvadó V, Brix H. Occurrence and behavior of emerging contaminants in surface water and a restored wetland. Chemosphere 2012;88:1083-1089.

33. Yang X, Chen F, Meng F, et al. Occurrence and fate of PPCPs and correlations with water quality parameters in urban riverine waters of the Pearl River Delta, South China. Environ. Sci. Pollut. Res. 2013:1-12.

34. Fram MS, Belitz K. Occurrence and concentrations of pharmaceutical compounds in groundwater used for public drinking-water supply in California. Sci. Total Environ. 2011;409: 3409-3417.

35. Kosma CI, Lambropoulou DA, Albanis TA. Occurrence and removal of PPCPs in municipal and hospital wastewaters in Greece. J. Hazard. Mater. 2010;179:804-817.

36. Conkle JL, White JR, Metcalfe CD. Reduction of pharmaceutically active compounds by a lagoon wetland wastewater treatment system in Southeast Louisiana. Chemosphere 2008;73: 1741-1748.

37. Park J. An approach for developing aquatic environmental risk assessment framework for pharmaceuticals in Korea. Korea Environment Institute. 2006.

38. Kim I, Tanaka H. Photodegradation characteristics of PPCPs in water with UV treatment. Environ. Int. 2009;35:793-802.

39. Benotti MJ, Trenholm RA, Vanderford BJ, Holady JC, Stanford BD, Snyder SA. Pharmaceuticals and endocrine disrupting compounds in US drinking water. Environ. Sci. Technol. 2009;43:597-603.

40. Bendz D, Paxeus NA, Ginn TR, Loge FJ. Occurrence and fate of pharmaceutically active compounds in the environment, a case study: Höje River in Sweden. J. Hazard. Mater. 2005; 122:195-204.

41. Nakada N, Tanishima T, Shinohara H, Kiri K, Takada H. 
Pharmaceutical chemicals and endocrine disrupters in municipal wastewater in Tokyo and their removal during activated sludge treatment. Water Res. 2006;40:3297-3303.

42. Zhao JL, Ying GG, Wang L, et al. Determination of phenolic endocrine disrupting chemicals and acidic pharmaceuticals in surface water of the Pearl Rivers in South China by gas chromatography-negative chemical ionization-mass spectrometry. Sci. Total Environ. 2009;407:962-974.

43. Hilton MJ, Thomas KV. Determination of selected human pharmaceutical compounds in effluent and surface water samples by high-performance liquid chromatography-electrospray tandem mass spectrometry. J. Chromatogr. A. 2003;1015:129-141.

44. Hernando MD, Heath E, Petrovic M, Barceló D. Trace-level determination of pharmaceutical residues by LC-MS/MS in natural and treated waters. A pilot-survey study. Anal. Bioanal. Chem. 2006;385:985-991.

45. Kolpin DW, Furlong ET, Meyer MT, et al. Pharmaceuticals, hormones, and other organic wastewater contaminants in US streams, 1999-2000: A national reconnaissance. Environ. Sci. Technol. 2002;36:1202-1211.

46. Brown KD, Kulis J, Thomson B, Chapman TH, Mawhinney DB. Occurrence of antibiotics in hospital, residential, and dairy effluent, municipal wastewater, and the Rio Grande in New Mexico. Sci. Total Environ. 2006;366:772-783.

47. Barnes KK, Kolpin DW, Furlong ET, Zaugg SD, Meyer MT, Barber LB. A national reconnaissance of pharmaceuticals and other organic wastewater contaminants in the United States-I) Groundwater. Sci. Total Environ. 2008;402:192-200.

48. Yu Y, Huang Q, Wang Z, Zhang K, Tang C, Cui J, Feng J, Peng X. Occurrence and behavior of pharmaceuticals, steroid hormones, and endocrine-disrupting personal care products in wastewater and the recipient river water of the Pearl River Delta, South China. J. Environ. Monit. 2011;13:871-878.

49. Behera SK, Kim HW, Oh JE, Park HS. Occurrence and removal of antibiotics, hormones and several other pharmaceuticals in wastewater treatment plants of the largest industrial city of Korea. Sci. Total Environ. 2011;409:4351-4360.

50. Klečka GM, Staples CA, Clark KE, van der Hoeven N, Thomas DE, Hentges SG. Exposure analysis of bisphenol A in surface water systems in North America and Europe. Environ. Sci. Technol. 2009;43:6145-6150.

51. Yoon Y, Ryu J, Oh J, Choi BG, Snyder SA. Occurrence of endocrine disrupting compounds, pharmaceuticals, and personal care products in the Han River (Seoul, South Korea). Sci. Total Environ. 2010;408:636-643.

52. Loos R, Locoro G, Comero S, et al. Pan-European survey on the occurrence of selected polar organic persistent pollutants in ground water. Water Res. 2010;44:4115-4126.

53. Morasch B, Bonvin F, Reiser H, et al. Occurrence and fate of micropollutants in the Vidy Bay of Lake Geneva, Switzerland. Part II: Micropollutant removal between wastewater and raw drinking water. Environ. Toxicol. Chem. 2010;29:1658-1668.

54. Köck-Schulmeyer M, Villagrasa M, López de Alda M, Céspedes-Sánchez R, Ventura F, Barceló D. Occurrence and behavior of pesticides in wastewater treatment plants and their environmental impact. Sci. Total Environ. 2013;458:466-476.

55. Hernando M, Mezcua M, Gómez M, Malato O, Agüera A,
Fernández-Alba A. Comparative study of analytical methods involving gas chromatography-mass spectrometry after derivatization and gas chromatography-tandem mass spectrometry for the determination of selected endocrine disrupting compounds in wastewaters. J. Chromatogr. A. 2004;1047:129-135.

56. Kuster M, López de Alda MJ, Hernando MD, Petrovic M, Martín-Alonso J, Barceló D. Analysis and occurrence of pharmaceuticals, estrogens, progestogens and polar pesticides in sewage treatment plant effluents, river water and drinking water in the Llobregat river basin (Barcelona, Spain). J. Hydrol. 2008;358;112-123.

57. Kumar KS, Priya SM, Peck AM, Sajwan KS. Mass loadings of triclosan and triclocarbon from four wastewater treatment plants to three rivers and landfill in Savannah, Georgia, USA. Arch. Environ. Contam. Toxicol. 2010;58:275-285.

58. Young TA, Heidler J, Matos-Pérez CR, et al. Ab initio and in situ comparison of caffeine, triclosan, and triclocarban as indicators of sewage-derived microbes in surface waters. Environ. Sci. Technol. 2008;42:3335-3340.

59. Li D, Kim M, Shim WJ, Yim UH, Oh JR, Kwon YJ. Seasonal flux of nonylphenol in Han River, Korea. Chemosphere 2004;56:1-6.

60. Wu Z, Zhang Z, Chen S, He F, Fu G, Liang W. Nonylphenol and octylphenol in urban eutrophic lakes of the subtropical China. Fresen. Environ. Bull. 2007;16:227-234.

61. Heberer T, Schmidt-Bäumler K, Stan H. Occurrence and distribution of organic contaminants in the aquatic system in Berlin. Part I: Drug residues and other polar contaminants in Berlin surface and groundwater. Acta Hydroch. Hydrob. 1998;26:272-278.

62. Collier AC. Pharmaceutical contaminants in potable water: potential concerns for pregnant women and children. EcoHealth 2007;4:164-171.

63. Schriks M, Heringa MB, van der Kooi MM, de Voogt P, van Wezel AP. Toxicological relevance of emerging contaminants for drinking water quality. Water Res. 2010;44:461-476.

64. WHO. World Health Organization. Guidelines for drinking-water quality. 4th ed. 2011.

65. USEPA. United States Environmental Protection Agency. National primary drinking water regulations-maximum contaminant levels. 2011.

66. Health Canada. Guidelines for Canadian drinking water quality-summary table. Water, air and climate change bureau, healthy environments and consumer safety branch, Ottawa, Ontario. 2012.

67. NJMRC. National health and medical research council. Australian drinking water guidelines. 2011.

68. EU. European Union. Water framework directive 2008/105/EC. European parliament and of the council. 2008.

69. SCHER. Scientific Committee on Health and Environmental Risks. Chemicals and the water framework directive: draft environmental quality standards-diclofenac, ethinylestradiol, $17 \beta$ -estradiol. 2011.

70. Gibs J, Stackelberg PE, Furlong ET, Meyer M, Zaugg SD, Lippincott RL. Persistence of pharmaceuticals and other organic compounds in chlorinated drinking water as a function of time. Sci. Total Environ. 2007;373:240-249. 
71. Nam SW, Jo BI, Yoon Y, Zoh KD. Occurrence and removal of selected micropollutants in a water treatment plant. Chemosphere 2014;95:156-165.

72. Rodriguez-Mozaz S, López de Alda MJ, Barceló D. Monitoring of estrogens, pesticides and bisphenol $\mathrm{A}$ in natural waters and drinking water treatment plants by solid-phase extractionliquid chromatography-mass spectrometry. J. Chromatogr. A 2004;1045:85-92.

73. Stackelberg PE, Gibs J, Furlong ET, Meyer MT, Zaugg SD, Lippincott RL. Efficiency of conventional drinking-water-treatment processes in removal of pharmaceuticals and other organic compounds. Sci. Total Environ. 2007;377:255-272.

74. Boleda MR, Galceran MT, Ventura F. Behavior of pharmaceuticals and drugs of abuse in a drinking water treatment plant (DWTP) using combined conventional and ultrafiltration and reverse osmosis (UF/RO) treatments. Environ. Pollut. 2011;159:1584-1591.

75. Vieno NM, Härkki H, Tuhkanen T, Kronberg L. Occurrence of pharmaceuticals in river water and their elimination in a pilot-scale drinking water treatment plant. Environ. Sci. Technol. 2007;41:5077-5084.

76. Gregory J, Duan J. Hydrolyzing metal salts as coagulants. Pure Appl. Chem. 2001;73:2017-2026.

77. Duan J, Gregory J. Coagulation by hydrolysing metal salts. Adv. Colloid Interface Sci. 2003;100-102:475-502.

78. Matilainen A, Vepsäläinen M, Sillanpää M. Natural organic matter removal by coagulation during drinking water treatment: A review. Adv. Colloid Interface Sci. 2010;159:189-197.

79. Nam SW, Choi DJ, Kim SK, Her N, Zoh KD. Adsorption characteristics of selected hydrophilic and hydrophobic micropollutants in water using activated carbon. J. Hazard. Mater. 2014;270:144-152.

80. Özacar M, Sengil IA. Evaluation of tannin biopolymer as a coagulant aid for coagulation of colloidal particles. Colloid. Surface. A. 2003;229:85-96.

81. Wang JP, Chen YZ, Ge XW, Yu HQ. Optimization of coagulation/flocculation process for a paper-recycling wastewater treatment using response surface methodology. Colloid. Surface. A. 2007;302:204-210.

82. Ye C, Wang D, Shi B, Yu J, Qu J, Edwards M, Tang H. Alkalinity effect of coagulation with polyaluminum chlorides: Role of electrostatic patch. Colloid. Surface. A. 2007;294:163-173.

83. Matamoros V, Salvadó V. Evaluation of a coagulation/flocculation-lamellar clarifier and filtration-UV-chlorination reactor for removing emerging contaminants at full-scale wastewater treatment plants in Spain. J. Environ. Manage. 2013;117:96-102.

84. Suárez S, Lema JM, Omil F. Pre-treatment of hospital wastewater by coagulation-flocculation and flotation. Bioresour. Technol. 2009;100:2138-2146.

85. Asakura H, Matsuto T. Experimental study of behavior of endocrine-disrupting chemicals in leachate treatment process and evaluation of removal efficiency. Waste Manage. 2009;29:1852-1859.

86. Choi KJ, Kim SG, Kim SH. Removal of antibiotics by coagulation and granular activated carbon filtration. J. Hazard. Mater. 2008;151:38-43.

87. Luo Y, Guo W, Ngo $\mathrm{HH}$, et al. A review on the occurrence of micropollutants in the aquatic environment and their fate and removal during wastewater treatment. Sci. Total Environ.
2014;473-474:619-641.

88. Thuy PT, Moons K, Van Dijk J, Viet Anh N, Van der Bruggen B. To what extent are pesticides removed from surface water during coagulation-flocculation? Water Environ. J. 2008;22: 217-223.

89. Adams C, Wang Y, Loftin K, Meyer M. Removal of antibiotics from surface and distilled water in conventional water treatment processes. J. Environ. Eng. 2002;128:253-260.

90. Stumm W, Morgan JJ, Drever JI. Aquatic Chemistry: Chemical equilibria and rates in natural waters. 3rd ed. New York: Wiley Interscience; 1996. p. 519-521.

91. Kovalova L, Siegrist H, von Gunten U, Eugster J, Hagenbuch M, Wittmer A. Elimination of micropollutants during post-treatment of hospital wastewater with powdered activated carbon, ozone, and UV. Environ. Sci. Technol. 2013;47: 7899-7908.

92. Hernández-Leal L, Temmink H, Zeeman G, Buisman C. Removal of micropollutants from aerobically treated grey water via ozone and activated carbon. Water Res. 2011;45: 2887-2896.

93. Snyder SA, Adham S, Redding AM, et al. Role of membranes and activated carbon in the removal of endocrine disruptors and pharmaceuticals. Desalination 2007;202:156-181.

94. Grover D, Zhou J, Frickers P, Readman J. Improved removal of estrogenic and pharmaceutical compounds in sewage effluent by full scale granular activated carbon: Impact on receiving river water. J. Hazard. Mater. 2011;185:1005-1011.

95. Yang X, Flowers RC, Weinberg HS, Singer PC. Occurrence and removal of pharmaceuticals and personal care products (PPCPs) in an advanced wastewater reclamation plant. Water Res. 2011;45:5218-5228.

96. Rossner A, Snyder SA, Knappe DR. Removal of emerging contaminants of concern by alternative adsorbents. Water Res. 2009;43:3787-3796.

97. Bolong N, Ismail AF, Salim MR, Matsuura T. A review of the effects of emerging contaminants in wastewater and options for their removal. Desalination 2009;239:229-246.

98. Korich D, Mead J, Madore M, Sinclair N, Sterling CR. Effects of ozone, chlorine dioxide, chlorine, and monochloramine on Cryptosporidium parvum oocyst viability. Appl. Environ. Microbiol. 1990;56:1423-1428.

99. Asano $\mathrm{T}$, Levine $\mathrm{AD}$. Wastewater reclamation, recycling and reuse: Past, present, and future. Water Sci. Technol. 1996;33:1-14.

100. Richardson SD. Disinfection by-products and other emerging contaminants in drinking water. TrAC-Trend. Anal. Chem. 2003;22:666-684.

101. Gallard H, von Gunten U. Chlorination of phenols: Kinetics and formation of chloroform. Environ. Sci. Technol. 2002;36: 884-890.

102. Westerhoff P, Yoon Y, Snyder S, Wert E. Fate of endocrine-disruptor, pharmaceutical, and personal care product chemicals during simulated drinking water treatment processes. Environ. Sci. Technol. 2005;39:6649-6663.

103. Kosjek T, Heath E. Applications of mass spectrometry to identifying pharmaceutical transformation products in water treatment. TrAC-Trend. Anal. Chem. 2008;27:807-820.

104. American Chemistry Council, 2008. The benefits of chlorine 
chemistry in water treatment. https://yosemite.epa.gov/sab\% 5CSABPRODUCT.nsf/EC591C83E0AE1B5A8525796700715 41A/\$File/ATT4WSEA.pdf.

105. Pinkston KE, Sedlak DL. Transformation of aromatic ether-and amine containing pharmaceuticals during chlorine disinfection. Environ. Sci. Technol. 2004;38:4019-4025.

106. Sim WJ, Lee JW, Oh JE. Occurrence and fate of pharmaceuticals in wastewater treatment plants and rivers in Korea. Environ. Pollut. 2010;158:1938-1947.

107. Christman RF, Norwood DL, Millington DS, Johnson JD, Stevens AA. Identity and yields of major halogenated products of aquatic fulvic acid chlorination. Environ. Sci. Technol. 1983;17:625-628.

108. Oliver BG. Dihaloacetonitriles in drinking water: Algae and fulvic acid as precursors. Environ. Sci. Technol. 1983;17:80-83.

109. von Gunten U. Ozonation of drinking water: Part I. Oxidation kinetics and product formation. Water Res. 2003;37:1443-1467

110. von Gunten U. Ozonation of drinking water: Part II. Disinfection and by-product formation in presence of bromide, iodide or chlorine. Water Res. 2003;37:1469-1487.

111. Šojić D, Despotović V, Orčić D, et al. Degradation of thiamethoxam and metoprolol by $\mathrm{UV}, \mathrm{O}_{3}$, and $\mathrm{UV} / \mathrm{O}_{3}$ hybrid processes: Kinetics, degradation intermediates and toxicity. $J$. Hydrol. 2012;472-473:314-327.

112. Rivas F, Gimeno O, Borralho T, Carbajo M. UV-C radiation based methods for aqueous metoprolol elimination. J. Hazard. Mater. 2010;179:357-362.

113. Jin J, El-Din MG, Bolton JR. Assessment of the UV/Chlorine process as an advanced oxidation process. Water Res. 2011;45:1890-1896.

114. Nam SW, Yoon Y, Choi DJ, Zoh KD. Degradation characteristics of metoprolol during UV/chlorination reaction and a factorial design optimization. J. Hazard. Mater. 2015;285:453-463.

115. Vilve M, Hirvonen A, Sillanpää M. Ozone-based advanced oxidation processes in nuclear laundry water treatment. Environ. Technol. 2007;28:961-968.

116. Sui Q, Huang J, Deng S, Yu G, Fan Q. Occurrence and removal of pharmaceuticals, caffeine and DEET in wastewater treatment plants of Beijing, China. Water Res. 2010;44:417-426.

117. Gerrity D, Gamage S, Holady JC, et al. Pilot-scale evaluation of ozone and biological activated carbon for trace organic contaminant mitigation and disinfection. Water Res. 2011;45: 2155-2165.

118. Kim JW, Jang HS, Kim JG, et al. Occurrence of pharmaceutical and personal care products (PPCPs) in surface water from Mankyung River, South Korea. J. Health Sci. 2009;55:249-258.

119. Huber MM, Ternes TA, von Gunten U. Removal of estrogenic activity and formation of oxidation products during ozonation of 17a-ethinylestradiol. Environ. Sci. Technol. 2004;38:5177-5186.

120. Bila D, Montalvão AF, Azevedo DA, Dezotti M. Estrogenic activity removal of $17 \beta$-estradiol by ozonation and identification of by-products. Chemosphere 2007;69:736-714.

121. Maniero MG, Bila DM, Dezotti M. Degradation and estrogenic activity removal of $17 \beta$-estradiol and $17 \alpha$-ethinylestradiol by ozonation and $\mathrm{O}_{3} / \mathrm{H}_{2} \mathrm{O}_{2}$. Sci. Total. Environ. 2008;407:105-115.

122. Sun Q, Deng S, Huang J, Yu G. Relationship between oxidation products and estrogenic activity during ozonation of 4-nonylphenol. Ozone Sci. Eng. 2008;30:120-126.

123. Altmann J, Ruhl AS, Zietzschmann F, Jekel M. Direct comparison of ozonation and adsorption onto powdered activated carbon for micropollutant removal in advanced wastewater treatment. Water Res. 2014;55:185-193.

124. Lee Y, von Gunten U. Oxidative transformation of micropollutants during municipal wastewater treatment: comparison of kinetic aspects of selective (chlorine, chlorine dioxide, ferrate(VI), and ozone) and non-selective oxidants (hydroxyl radical). Water Res. 2010;44:555-566.

125. Wert EC, Rosario-Ortiz FL, Drury DD, Snyder SA. Formation of oxidation byproducts from ozonation of wastewater. Water Res. 2007;41:1481-1490.

126. Wert EC, Rosario-Ortiz FL, Snyder SA. Effect of ozone exposure on the oxidation of trace organic contaminants in wastewater. Water Res. 2009;43:1005-1014.

127. Pereira RO, de Alda ML, Joglar J, Daniel LA, Bardeló D. Identification of new ozonation disinfection byproducts of $17 \beta$-estradiol and estrone in water. Chemosphere 2011;84: 1535-1541.

128. Richardson SD, Thruston Jr AD, Caughran TV, Chen PH, Collette TW, Floyd TL. Identification of new ozone disinfection byproducts in drinking water. Environ. Sci. Technol. 1999;33:3368-3377.

129. Schmidt CK, Brauch HJ. N,N-Dimethylsulfamide as precursor for N-Nitrosodimethylamine (NDMA) formation upon ozonation and its fate during drinking water treatment. Environ. Sci. Technol. 2008;42:6340-6346.

130. Zhao YY, Boyd JM, Woodbeck M, et al. Formation of N-nitrosamines from eleven disinfection treatments of seven different surface waters. Environ. Sci. Technol. 2008;42:4857-4862.

131. Sarathy SR, Mohseni M. The impact of $\mathrm{UV} / \mathrm{H}_{2} \mathrm{O}_{2}$ advanced oxidation on molecular size distribution of chromophoric natural organic matter. Environ. Sci. Technol. 2007;41:8315-8320.

132. Jo CH, Dietrich AM, Tanko JM. Simultaneous degradation of disinfection byproducts and earthy-musty odorants by the $\mathrm{UV} / \mathrm{H}_{2} \mathrm{O}_{2}$ advanced oxidation process. Water Res. 2011;45: 2507-2516.

133. Bazri MM, Barbeau B, Mohseni M. Impact of $\mathrm{UV} / \mathrm{H}_{2} \mathrm{O}_{2}$ advanced oxidation treatment on molecular weight distribution of NOM and biostability of water. Water Res. 2012;46:5297-5304.

134. Dotson AD, Keen VS, Metz D, Linden KG. UV/ $\mathrm{H}_{2} \mathrm{O}_{2}$ treatment of drinking water increases post-chlorination DBP formation. Water Res. 2010;44:3703-3713.

135. Metz DH, Meyer M, Dotson A, Beerendonk E, Dionysiou DD. The effect of $\mathrm{UV} / \mathrm{H}_{2} \mathrm{O}_{2}$ treatment on disinfection by-product formation potential under simulated distribution system conditions. Water Res. 2011;45:3969-3980.

136. Shah AD, Krasner SW, Lee CFT, von Gunten U, Mitch WA. Trade-offs in disinfection byproduct formation associated with precursor preoxidation for control of N-nitrosodimethylamine formation. Environ. Sci. Technol. 2012;46:4809-4818.

137. Chu W, Gao N, Yin D, Krasner SW, Mitch WA. Impact of $\mathrm{UV} / \mathrm{H}_{2} \mathrm{O}_{2}$ pre-oxidation on the formation of haloacetamids and other nitrogenous disinfection byproducts during chlorination. Environ. Sci. Technol. 2014;48:12190-12198. 